\title{
LOW IRON LEVEL IS RELATED TO TELOGEN EFFLUVIUM IN WOMEN
}

\author{
MD. MANJURUL KARIM ${ }^{1}$, MD. ABDUL WAHAB ${ }^{2}$, LUBNA KHONDOKER ${ }^{3}$, MD. SHIRAJUL ISLAM KHAN ${ }^{4}$
}

\begin{abstract}
A case-control study conducted in the Department of Dermatology and Venereology of Bangabandhu Sheikh Mujib Medical University, Dhaka from July 2008- December 2010. A total 60 female patients of telogen effluvium attending in outpatient department (OPD) were enrolled in the study with 30 having hair loss considered as case (Group-A) and another 30 females had no history of hair loss were considered as control (Group-B). The study included 60 patients and the mean age were $25.4 \pm 7$ years ranging from 18 to 42 years in group $A$ and $24.8 \pm 5.6$ years ranging from 17 to 36 years in group $B$. Maximum number was found in the age group of 21-30 years in both groups and nearly three fourth (73.4\%) patients were unmarried in group $A$ and $18(60.0 \%)$ in group B. Most of the patients were student in both groups, which were $21(70.0 \%)$ and $17(56.7 \%)$ in group A and group $B$ respectively and majority of the the patients were HSC level in both groups, 15(50.0\%) and $14(46.7 \%)$ in Group A and Group B respectively. Most of the patients came from middle class, which were $20(66.7 \%)$ and $16(53.3 \%)$ in group $A$ and group $B$ respectively. The mean serum ferritin were $18.8 \pm 8.1 \mathrm{~g} / \mathrm{L}$ ranging from 4.5 to $36.54 \mathrm{~g} / \mathrm{L}$ and $36.6 \pm 9.9 \mathrm{mg} / \mathrm{L}$ ranging from 18.46 to $56.3 \mathrm{mg} /$ $L$ in group $A$ and group $B$ respectively. The mean $H b$ level was $11.5 \pm 1.4 \mathrm{gm} /$ dl ranging from 8.5 to $14.0 \mathrm{gm} / \mathrm{dl}$ in group $A$ and $12.8 \pm 1.1 \mathrm{gm} / \mathrm{dl}$ ranging from 10.5 to $14.5 \mathrm{gm} / \mathrm{dl}$ in group $B$. The mean difference of $\mathrm{Hb}$ level was statistically significant $(p<0.05)$ between two groups in unpaired $t$-test. It can be concluded that low iron level is associated with telogen effluvium in women.
\end{abstract}

\section{Introduction}

Iron deficiency anaemia is a common nutritional deficiency. The prevalence of iron deficiency anaemia in premenopausal women is estimated to be $12 \% .^{1}$ Iron deficiency is the most common cause of telogen effluvium in premenopausal women due to menstrual blood loss \& pregnancy. Telogen effluvium is a form of non-scarring alopecia characterized by excessive diffuse hair shedding. ${ }^{2}$ Although hormonal imbalance $\&$ medications are the most common causes of telogen effluvium in postmenopausal women, iron deficiency due to gastrointestinal blood loss \& malabsorption should not be ruled out. ${ }^{3}$ Besides being a trigger for telogen effluvium where the majority of hair shedding occur, iron deficiency can also be the most likely underlying cause. It is understood that levels of iron play a significant role in various body functions but it is also essential for sustaining normal growth and maintenance of hair. As a continuously growing and metabolically active tissue, hair requires high level available nutrients for hair cell DNA synthesis and development. ${ }^{4}$ Iron is fundamentally required by the body to form adequate numbers of normal red blood cells. These are the cells that carry oxygen throughout the body. The key protein in red blood cells to which oxygen attaches is called haemoglobin. Haemoglobin is a very iron rich biochemical. ${ }^{5}$

Iron deficiency is a common and reversible cause of telogen effluvium. ${ }^{6}$ No specific therapy is required for most patients with acute telogen effluvium. ${ }^{7}$ But if the course is prolonged or if history or physical examination suggests an abnormality, iron status should be determined to find any deficiency of iron. Moreover, hair loss treatments can be expensive, so it is always a good idea to check iron status before starting treatment. ${ }^{8}$ Several studies were conducted to find out the relation between iron deficiency and hair loss. But conflicting observational data have failed to determine whether an association exists between alopecia and iron deficiency in women. Here an endeavor had made to find out the relation between iron level and telogen effluvium.

\section{Materials and Methods}

This was a case-control study conducted in the Department of Dermatology and Venereology of Bangabandhu Sheikh Mujib Medical University, Shahbag, Dhaka from July 2008-December 2010. A total sixty female patients of telogen effluvium attending in outpatient department(OPD) were enrolled in the study with 30 having hair loss considered as case(Group-A) and another 30 females had no history of hair loss were considered as control(Group-B). Purposive type of non probability sampling technique was followed in this study.

1. MD Student, Department of Dermatology \& Venereology, BSMMU

2. Associate Professor, Department of Dermatology \& Venereology, BSMMU

3. Specialist in Dermatology \& Venereology, BSMMU

4. Specialist in Dermatology \& Venereology, Combined Military Hospital (CMH)

Bangladesh J Medicine 2010; 21 : 84-89 
BJM Vol. 21 No. 2

Inclusion criterias of patients include:

1. Clinically diagnosed telogen effluvium.

a. History of diffuse hair loss for more than 6 months.

b. Daily hair loss count more than 100 .

c. Positive pull test.

d. Absence of central parting and miniaturized vellus hair(to exclude female pattern hair loss)..

2. Patient who gave informed consent.

3. Women with childbearing age.

Exclusion criterias of patients include:

1. Not willing to participate.

2. Persons taking iron supplementation.

3. Patients with scalp psoriasis, seborrhiec dermatitis and fungal infection.

4. Patients with area of total alopecia or sign of inflammatory scalp dermatitis.

5. Patients with hypothyroidism or hyperthyroidism.

6. Patients with female patterned hair loss (FPHL).

7. Patients with known triggering event for hair loss like pregnancy, surgery, febrile illness etc.

8. Patients with anticancer chemotherapy and immunosuppressive therapy.

9. Patients with concomitant chronic systemic illness.

10. Patients with trichodynia.

11. Children and postmenopausal women.

Inclusion criterias of control group:

1. Women with childbearing age without a history of hair loss.

2. Persons who gave informed consent.

Exclusion criteria of control group:

1. Not willing to participate.

2. Persons taking iron supplementation.

3. Children and postmenopausal women.

\section{Procedure of the study:}

All women patients of hair loss attending in dept. of Dermatology, BSMMU were seen. According to a structured questionnaire, their particulars and history was taken.

Then patients for the study were selected on the basis of history, clinical examination and inclusion and
Low Iron Level is Related to Telogen Effluvium in Women

exclusion criterias. Thorough general physical examination of all the study subjects was done to exclude any systemic illness. Diffuse hair loss patients without any known triggering factors were included in the study. Diagnosis of telogen effluvium was confirmed by daily hair count and hair pull test and absence of miniaturized villus hair or widening of central parting (to exclude female pattern hair loss). Then from the selected patients blood samples were collected with aseptic measures for estimation of serum ferritin, serum free T4, thyroid stimulating hormone(TSH), blood glucose, Heamoglobin level, total count of $\mathrm{WBC}(\mathrm{TC})$, differential count of $\mathrm{WBC}(\mathrm{DC})$, erythrocyte sedimentation rate(ESR), serum ALT and serum creatinine. The tests other than serum ferritin and heamoglobin level were done to exclude the metabolic and systemic causes of telogen effluvium. Serum ferritin, free T4, TSH were done in dept of Biochemistry, BSMMU, Dhaka. Other tests were done in Dept of clinical pathology, BSMMU, Dhaka. At the same time a control group of healthy women without hair loss were selected with exclusion and inclusion criterias and serum ferritin, Hb, TC, DC, ESR were done. Data were collected from biochemical reports and standared questionnaire. Reports of cases and controls were then compared.

\section{Collection of blood samples:}

With all aseptic precautions from all study subjects $5 \mathrm{ml}$ of blood was collected from median cubital vein by disposable plastic syringe. The needle was detached from the nozzle and blood was transferred immediately into dry clean plastic test tube. The blood collected in dry test tubes was allowed to clot and then was centrifused. Separated serum was collected into micro-centrifused tubes and was appropriately labeled and stored in freezer at $-35^{\circ} \mathrm{C}$ until analytical measurement of serum. Blood was taken for one time from each study subject for estimation of serum ferritin and all other investigations.

\section{Method of estimation of serum ferritin:}

Microparticle Enzyme Immunoassay (MEIA) technology was used for the quantitative determination of ferritin in human serum in the dept of Biochemistry, BSMMU, Dhaka.

Ethical consideration:

1) All informations of benefits and hazards were delivered to the patient.

2) Patients were informed about the methodology, objective and purposes of the study.

3) They were made free to give consent.

4) Information's obtained from the patient were kept confidential. 
5) Thesis protocol was accepted by the University ethical review committee.

\section{Data collection technique:}

Relevant data were collected in a preformed data collection sheet for each of the patient from their history, clinical examination and biochemical reports.

Analysis of the data and results:

All data checked and verified thoroughly to reduce the inconsistency. Data were collected and processed by SPSS (statistical package of social science) version 12.0. The quantitative data were expressed as mean and standard deviation (mean+SD) for normally distributed variables. The chi-square test and student $t$ test were used for comparison between two groups.

\section{Results}

This was a case-control study conducted in the department of Dermatology and Venereology of Bangabandhu Sheikh Mujib Medical University, Shahbag, Dhaka. The main objective of the study was to find out the relationship between low iron level and telogen effluvium in women. A total sixty female patients were enrolled in the study with thirty having hair loss considered as case (Group-A) and another thirty females had no history of hair loss were considered as control (Group-B).

The study included 60 patients and they were divided into four age groups. The mean age were $25.4 \pm 7$ years ranging from 18 to 42 year in group A and $24.8 \pm 5.6$ years ranging from 17 to 36 years in group $B$. Maximum number was found in the age group of 2130 years in both groups. The mean age difference was not statistically significant $(\mathrm{p}>0.05)$ in unpaired ttest.

Nearly three fourth (73.4\%) patients were unmarried in group A and $18(60.0 \%)$ in group B and the difference was not statistically significant $(p>0.05)$ regarding the marital status in chi square test. Most of the patients was student in both groups, which were $21(70.0 \%)$ and $17(56.7 \%)$ in group A and group B respectively. Housewife was $9(30.0 \%)$ in group $A$ and $9(30.0 \%)$ in Group B. No service holder in Group A but 4(13.3\%) were in group B.. The difference was not statistically significant $(p>0.05)$ regarding the occupation in chi square test.

Majority of the the patients were HSC (higher secondary school certificate) level in both groups, $15(50.0 \%)$ and $14(46.7 \%)$ in Group A and Group B respectively. However, $11(36.7 \%)$ and $13(43.3 \%)$ was graduate in Group A and Group B respectively. The difference was not statistically significant $(p>0.05)$ regarding the level of education in chi square test. Most of the patients came from middle class, which were $20(66.7 \%)$ and $16(53.3 \%)$ in group A and group B respectively. Upper class found $10(33.3 \%)$ in Group A and $14(46.7 \%)$ in Group B. The difference was not statistically significant $(p>0.05)$ regarding the socioeconomic status in chi square test.

Low serum ferritin level was found 23(76.7\%) and $5(16.7 \%)$ in group A and Group B respectively. The mean serum ferritin were $18.8 \pm 8.1 \mathrm{mg} / \mathrm{L}$ ranging from 4.5 to $36.54 \mathrm{mg} / \mathrm{L}$ and $36.6 \pm 9.9 \mathrm{mg} / \mathrm{L}$ ranging from 18.46 to $56.3 \mathrm{mg} / \mathrm{L}$ in group A and group B respectively. The mean difference of serum ferritin level was statistically significant $(\mathrm{p}<0.05)$ between two groups in unpaired t-test.

Low $\mathrm{Hb}$ level was found in $10(33.3 \%)$ and $2(6.7 \%)$ in group A and group B respectively. The mean $\mathrm{Hb}$ level was $11.5 \pm 1.4 \mathrm{gm} / \mathrm{d}$ ranging from 8.5 to $14.0 \mathrm{gm} / \mathrm{dl}$ in group A and $12.8 \pm 1.1 \mathrm{gm} / \mathrm{dl}$ ranging from 10.5 to 14.5 $\mathrm{gm} / \mathrm{dl}$ in group $\mathrm{B}$. The mean difference of $\mathrm{Hb}$ level was statistically significant $(p<0.05)$ between two groups in unpaired t-test.

Table-I

Distribution of the study patients according to age $(n=60)$

\begin{tabular}{|c|c|c|c|c|c|}
\hline \multirow[t]{2}{*}{$\begin{array}{l}\text { Age group } \\
\text { (years) }\end{array}$} & \multicolumn{2}{|c|}{$\begin{array}{c}\text { Group A } \\
(\mathrm{n}=30)\end{array}$} & \multicolumn{2}{|c|}{$\begin{array}{c}\text { Group B } \\
(\mathrm{n}=30)\end{array}$} & \multirow[t]{2}{*}{$\begin{array}{c}\mathrm{P} \\
\text { value }\end{array}$} \\
\hline & $\mathrm{n}$ & $\%$ & $\mathrm{n}$ & $\%$ & \\
\hline \multirow[t]{2}{*}{$£ 20$} & 9 & & 8 & & \\
\hline & & 30.0 & & 26.6 & \\
\hline $21-30$ & 15 & 50.0 & 16 & 53.3 & \\
\hline $31-40$ & 5 & 16.7 & 6 & 20 & \\
\hline$>41$ & 1 & 3.3 & 0 & 0.0 & \\
\hline Mean $\pm S D$ & \multicolumn{2}{|c|}{$25.4 \pm 7$} & $24.8 \pm 5.6$ & \multicolumn{2}{|r|}{$0.741^{\mathrm{ns}}$} \\
\hline Range (min & ax) & $(18-4$ & -2) & $-36)$ & \\
\hline
\end{tabular}

$\mathrm{P}$ value reached from chi square test.

Table II

Distribution of the study patients by marital status $(n=60)$

\begin{tabular}{lccccc}
\hline Marital status & \multicolumn{2}{c}{$\begin{array}{c}\text { Group A } \\
(\mathrm{n}=30)\end{array}$} & \multicolumn{2}{c}{$\begin{array}{c}\text { Group B } \\
(\mathrm{n}=30)\end{array}$} & $\begin{array}{c}\mathrm{P} \\
\text { value }\end{array}$ \\
& $\mathrm{n}$ & $\%$ & $\mathrm{n}$ & $\%$ & \\
\hline Unmarried & 22 & 73.4 & 18 & 60.0 & 0.199 \\
Married & & 8 & 26.6 & 12 & 40.0 \\
\hline
\end{tabular}

$\mathrm{P}$ value reached from chi square test. 
BJM Vol. 21 No. 2

Table III

Distribution of the study patients according to occupation $(n=60)$

\begin{tabular}{lccccc}
\hline Occupation & \multicolumn{2}{c}{$\begin{array}{c}\text { Group A } \\
(\mathrm{n}=30)\end{array}$} & \multicolumn{2}{c}{$\begin{array}{c}\text { Group B } \\
(\mathrm{n}=30)\end{array}$} & $\begin{array}{c}\mathrm{P} \\
\text { value }\end{array}$ \\
& $\mathrm{n}$ & $\%$ & $\mathrm{n}$ & $\%$ & \\
\hline Student & 21 & 70.0 & 17 & 56.7 & \\
Housewife & 9 & 30.0 & 9 & 30.0 & 0.328 \\
Service holders & 0 & 0.0 & 4 & 13.3 & \\
\hline
\end{tabular}

$\mathrm{P}$ value reached from chi square test.

Table IV

Distribution of the study patients according to education $(n=60)$

\begin{tabular}{lccccc}
\hline Education & \multicolumn{2}{c}{$\begin{array}{c}\text { Group A } \\
(\mathrm{n}=30)\end{array}$} & \multicolumn{2}{c}{ Group B } & P \\
& $\mathrm{n}$ & $\%$ & $\mathrm{n}=30)$ & value \\
\hline SSC & 4 & 13.3 & 3 & 10.0 & \\
HSC & 15 & 50.0 & 14 & 46.7 & 0.915 \\
Graduate & 11 & 36.7 & 13 & 43.3 & \\
\hline
\end{tabular}

$\mathrm{P}$ value reached from chi square test.

Table-V

Distribution of the study patients according to economic status $(n=60)$

\begin{tabular}{lccccc}
\hline $\begin{array}{l}\text { Economic } \\
\text { status }\end{array}$ & \multicolumn{2}{c}{$\begin{array}{c}\text { Group A } \\
(\mathrm{n}=30)\end{array}$} & \multicolumn{2}{c}{$\begin{array}{c}\text { Group B } \\
(\mathrm{n}=30)\end{array}$} & $\begin{array}{c}\mathrm{P} \\
\text { value }\end{array}$ \\
\hline Upper & $\mathrm{n}$ & $\%$ & $\mathrm{n}$ & $\%$ & \\
Middle & 10 & 33.3 & 14 & 46.7 & 0.457 \\
\hline
\end{tabular}

$\mathrm{P}$ value reached from chi square test.

Table VI

Distribution of the study patients according to serum ferritin and $\mathrm{Hb}$ level (n-60)

\begin{tabular}{lccccc}
\hline Investigations & \multicolumn{2}{c}{$\begin{array}{c}\text { Group A } \\
(\mathrm{n}-30) \\
\text { Low }\end{array}$} & $\begin{array}{c}\text { Group B } \\
(\mathrm{n}-30)\end{array}$ & $\begin{array}{c}\mathrm{P} \\
\text { value }\end{array}$ \\
\hline $\mathrm{SF}(\mathrm{mg} / \mathrm{L})$ & 23 & $18.8 \pm$ & 5 & $36.6 \pm$ & 0.001 \\
& $(76.7 \%)$ & 8.1 & $(16.7 \%)$ & 9.9 & \\
$($ min-max) & $(4.5-36.54)$ & $(18.46-56.3)$ & \\
\hline $\mathrm{Hb}(\mathrm{gm} / \mathrm{dl})$ & 10 & $11.5 \pm$ & 2 & $12.8 \pm$ & 0.001 \\
& $(33.3 \%)$ & 1.4 & $(6.7 \%)$ & 1.1 & \\
(min-max) & & $(8.5-14.0)$ & \multicolumn{4}{c}{$(10.5-14.5)$} \\
\hline
\end{tabular}

$\mathrm{P}$ value reached from unpaired t-test

Serum ferritin-Low $<22 \mu \mathrm{gm} / \mathrm{L}$

Normal range-22-120 $\mu \mathrm{gm} / \mathrm{L}$

Haemoglobin - Low $<11.5 \mathrm{gm} / \mathrm{dl}$

Normal range-11.5-16gm/dl
Low Iron Level is Related to Telogen Effluvium in Women

\section{Discussion}

A case-control study conducted in the Department of Dermatology and Venereology of Bangabandhu Sheikh Mujib Medical University, Shahbag, Dhaka. This study included only premenopausal women, age range was 17 to 42 years not similar to a case-control study in 1993 by Kantor et all of 106 female subjects aged 18 to 70 years presenting with alopecia. They included premenopausal and postmenopausal both group of patients. ${ }^{9}$ Also not similar to a cross sectional study by Amade Bregy and Ralph Trueb of total 181 females, where mean age of 22 tellogen effluvium patients was 39.23 years(range, $13-60) .5$

Data showed that highest percentage patients with telogen effluvium were in the age group 21 to 30 years $(50.0 \%)$. This is probably because these age group patients were more concerned about their hair loss. For the age matching the present study campared the mean ages of cases and controls and found no statistically significant difference between the two groups.

Nearly three fourth $(73.4 \%)$ patients were unmarried in group A and 20(60.0\%) in group B. Most of the patients were student in both groups, which were $21(70.0 \%)$ and $17(56.7 \%)$ in group A and group B respectively. Majority of the patients were in HSC level, $15(50.0 \%)$ in group A and $14(46.7 \%)$ in group B, however $11(36.7 \%)$ and. Most of the patients came from middle class, which were $20(66.7 \%)$ and $16(53.3 \%)$ in group A and group B respectively. This is because these groups of women have the habit of inadequate diet. So along with menstrual blood lose they have dietary iron deficiency. The study compared the mean of marital status, occupation, educational status and economic status among the cases and controls. No significant difference was found between the two groups of patients. This was done to reduce the differences in two groups of population.

The present work demonstrated that the serum ferritin levels were significantly decreased in telogen effluvium patients compared to control group. Both groups were categorised for serum ferritin levels using a cut-off point $22 \mu \mathrm{gm} / \mathrm{L}$ (official lowest value for female used in Dept of Biochemistry, BSMMU). Low serum ferritin level were found $23(60.5 \%)$ and $5(16.7 \%)$ in group A and Group B respectively. The mean serum ferritin levels were $18.8 \pm 8.1 \mathrm{mg} / \mathrm{L}$ ranging from 4.5 to $36.5 \mathrm{mg} / \mathrm{L}$ in group A and $36.6 \pm 9.9 \mathrm{mg} / \mathrm{L}$ ranging from 18.5 to $56.3 \mathrm{mg} / \mathrm{L}$ in group B. The mean difference of serum ferritin level was statistically significant $(p<0.05)$ between two groups in unpaired t-test.

Low Hemoglobin (Hb) level was found in 10(33.3\%) and $2(6.7 \%)$ in cases and controls respectively. The 
mean $\mathrm{Hb}$ level was $11.5 \pm 1.4 \mathrm{gm} / \mathrm{dl}$ with ranged from 8.5 to $14.0 \mathrm{gm} / \mathrm{dl}$ in cases and $12.8 \pm 1.1 \mathrm{gm} / \mathrm{dl}$ with ranged from 10.5 to $14.5 \mathrm{gm} / \mathrm{dl}$ in controls. The mean difference of $\mathrm{Hb}$ level was statistically significant $(\mathrm{p}<0.05)$ between two groups in unpaired t-test. It reflects that telogen effluvium patients are also associated with anaemia. This agrees with Rushton et al who showed that serum ferritin concentration may be a factor in non anaemic women and telogen effluvium. Rushton et al in a case-control study quantitatively evaluated 100 women who presented with diffuse alopecia and compared with 20 controls. Among 100 women with hair loss 50 were selected for biochemical and heamatological investigations. Among them seventeen(34\%) had changes in iron metabolism, while in thirty $\operatorname{six}(72 \%)$ serum ferritin levels were below the lowest control value. As serum ferritin levels were reduced in $72 \%$ and this suggest that iron stores in non essential tissues such as scalp hair may be more important than has so far been recognized. 10 This is also supported by his another study with 200 women where found that sixty five percent of women had serum ferritin levels below $40 \mu \mathrm{gm} / \mathrm{L}$, the lowest control value obtained in women without hair loss. 11

It is also supported by Nidal A Obaidat who concluded their study by stating that there was a significant association between low serum ferritin levels and chronic telogen effluvium. In their study mean serum ferritin levels between patients and controls were $18.7 \mathrm{ng} / \mathrm{ml}$ and $47.6 \mathrm{ng} / \mathrm{ml}$ respectively which was statistically significant $(\mathrm{p}<0.05) .{ }^{12}$

But in a case-control study by Kantor et al of 106 female subjects aged 18 to 70 years presenting with alopecia, the 30 subjects of telogen effluvium(TE) did not have significantly decreased serum ferritin concentration compared with 11 female control subjects(mean 50.1 versus $59.5 \mathrm{ng} / \mathrm{ml}$ respectively). They found that the mean ferritin level were significantly lower in androgenic alopecia and alopecia areata but not in telogen effluvium and alopecia areata totalis/universalis. 9

In a cross sectional study of a total 181 female, 22 was with telogen effluvium and 159 were female pattern hair loss. The mean serum ferritin level was $40.09 \mathrm{igm} / 1$ (range 2-209). They found no correlation between ferritin levels<10igm/1 whether in female pattern hair loss(FPHL) or tellogen effluvium (TE) patients. 5

Although the number of subjects in my study was rather small, a recent case-control study involved just 60 women, in which 34 were patients with hair loss and 26 were healthy control group. Their conclusion was similar to present study in that serum ferritin levels were significantly decreased in telogen effluvium patients compared to control group. ${ }^{14}$ However, Sinclair reported that no direct relationship between low serum ferritin and hair loss can be established. They concluded that usefulness of serum ferritin in routine investigation of women with chronic diffuse telogen hair loss and hence the role of iron supplementation therapy in management of hair loss are unlear. ${ }^{14}$

Previous authors claimed conflicting results; some suggesting an association between telogen effluvium and decreased iron stores, while others do not. Different authors used different range of serum ferritin level. Most previous studies included other types of hair loss in addition to chronic telogen effluvium and some of them addressed both men and women as patients.

Though there were some limitations in the study, it was first time in a developing country like Bangladesh where iron deficiency is a common nutritional problem. So the findings of the study should serve as an epidemiologic stepping stone from which further research, including clinical trials of iron therapy in hair loss patients can be launched. As ferritin levels accurately reflect body iron stores, however the present study clearly demonstrates an association between low iron stores and telogen effluvium in women.

W.F. Bergfield et al in a review article said "we believe that treatment for hair loss is enhanced when iron deficiency, with or without anaemia is treated. Treating iron deficiency without anaemia is controversial. Treatment of nutritional iron deficiency anaemia includes adequate dietary intake and oral iron supplementation. ${ }^{8}$

Chronic telogen effluvium is unlikely to resolve rapidly, but it is reassuring that hair loss will not progress to baldness. Decreased Hemoglobin level $(\mathrm{Hb})$ and seum ferritin levels are best corrected with oral iron therapy, which is safe, relatively inexpensive and generally well tolerated. The normalisation of levels may take 4 to 6 months or longer and therapy may be discontinued ones these levels exceeds 70 ng/ml. 12

\section{Conclusion}

It can be concluded that low iron level is associated with telogen effluvium in women.. Therefore Hemoglobin level and serum ferritin level may be of value in the evaluation of diffuse hair loss in women. 
BJM Vol. 21 No. 2

\section{Recommendations}

1) To evaluate the patients with diffuse hair loss Heamoglobin level and serum ferritin level would be a value, so it may be done routinely in hair loss patients.

2) A large scale study with adequate time and resources should be carried out in our country where iron deficiency as well as hair loss is a common problem especially in women.

\section{References:}

1. Pierre SAS, Vercellotti GM, Donovan JC, Hordinsky MK. Iron deficiency and diffuse non-scarring scalp alopecia in women: more pieces to the puzzle. Journal of the American Academy of Dermatology 2010; 63(6): 1070-1076.

2. Hughes et all. Telogen Effluvium-Overview. eMedicineDermatology2006. Retrieved February 02, 2009, from http://emedicine.medscape.com/ article/ 1071516

3. Trost LB, Bergfeld WF \& CalogerarE. The diagnosis and treatment of iron deficiency and potential relationship to hair loss. J AM Acad Dermatol 2006; 54(5): 824-44.

4. Tony Pearce RN. Iron Deficiency and Hair Loss- an Interpretation . RetrievedFebruary 10,2009from http: / / www.hairlossclinic.com.au/articles / Iron_Deficiency_and_Hair_Loss.html.

5. Bregy A, Trueb RM. No association between serum ferritin levels $>10$ igm/L and hair loss activity in women. Dermatology 2008; 217: 1-6.
Low Iron Level is Related to Telogen Effluvium in Women

6. Thomas J. Androgenic alopecia-Current status. Indian J Dermatol 2005; 50(4):179-190.

7. Shrivastava SB. Diffuse hair loss in adult female: Approach to diagnosis and management. IJDVL 2009; 75(1):20-28.

8. James WD, Berger TG, \& Elston DM. 'Diseases of the skin appendages' in Andrews diseases of the skinclinical dermatology.10th edition. USA: Saunders Elsevier; 2006. pp-749-62.

9. Kantor J, Kssler LJ, Brooks DG, \& Cotsarelis G. Decreased serum ferritin is associated with alopecia in women. J Invest Dermatol 2003; 125(5): 985-8

10. Rushton DH, Ramsay ID, James KC, Noris MJ, Gilkes JH. Biochemical and trichological characterization of diffuse alopecia in women. British J Dermato l1990;123:187-197.

11. Rushton DH. Nutritional factors and hair loss. Review of clinical and experimental Dermatology2002; 27:396-404.

12. Obaidat NA, Rawashdeh BT, Wreikat ARA. A potential relationship between telogen effluvium and iron deficiency in adult females. JRMS 2005; 12(1):62-66.

13. Hamad WAM, Said AF, Hamid AA. Role of some trace elements in the pathogenesis of telogen effluvium in Egyptian females. J Egypt women Dermatol Soc 2010; 7: 44-48

14. Sinclair R. There is no clear association between low serum ferritin and chronic diffuse telogen hair loss. Br J Dermatol 2002; 147:982-984.

15. Sinclair R. Chronic telogen effluvium or early androgenic alopecia. International J Dermatology2004; 43:842-843. 